HORTSCIENCE 26(5):594-596. 1991

\title{
Adventitious Shoot Production from a Vireya Hybrid of Rhododendron
}

\author{
Giovanni Iapichino', Tony H.H. Chen, and Leslie H. Fuchigami \\ Department of Horticulture, Oregon State University, Corvallis, \\ OR 97331
}

Additional index words. tissue culture, plant growth regulators, organogenesis

\begin{abstract}
An efficient adventitious shoot production protocol has been developed for Rhododendron laetum $\times$ aurigeranum. Shoot tips taken from greenhouse-grown plants were cultured on Anderson's medium supplemented with $74 \mu \mathrm{M} 2 \mathrm{iP}$. Axillary shoots were excised and cultured on medium containing $23 \mu \mathrm{M}$ IAA and $74 \mu \mathrm{M} 2 \mathrm{iP}$. After 6 months, brown callus developed at the cut surfaces of the shoot-tip explants. This callus produced many adventitious shoots (up to 70 per explant). Clusters of adventitious shoots were divided, subculture, and continued to proliferate shoots. An estimated 1600 -fold increase in the number of shoots could be readily achieved in 6 months. In vitro rooting of adventitious shoots was accomplished in 4 weeks. Seventy-three percent of shoots rooted on 1/4 strength Anderson's medium supplemented with 28 MM IAA. Plantlet survival was $100 \% 3$ weeks after transfer to soil. Chemical names used: $1-\mathrm{H}$ indole-3-acetic acid (MA); N-(3 -methy1-2-butenyl) -1H-purine-6 amine (2iP).
\end{abstract}

The genus Rhododendron, section Vireya, comprises $\approx 300$ species endemic to Southeast Asia (Sleumer, 1966). Almost half of the 300 Vireya species, including the species $R$. laetum J.J. Smith and $R$. aurigeranum Sleumer, are native to New Guinea, which lies between lat. $2^{\circ}$ and $12^{\circ} \mathrm{S}$. According to the Royal Horticultural Society (Leslie, 1980), Vireya rhododendrons are classified as "normally requiring greenhouse protection during the winter months". Those species native to low altitudes in New Guinea are irreparably damaged if exposed, even for a short time, to temperatures below 0C (Withers, 1984). Since Vireya rhododendrons do not require a resting period, they may flower at any time of the year. Therefore, they may have potential as greenhouse-grown ornamental plants. Moreover, they represent a source of breeding material for the improvement of hardy rhododendron flower quality. Vireya flowers range from $<1 \mathrm{~cm}$ to $10 \mathrm{~cm}$ in length and have a variety of colors, from white to yellow, from orange to deep red; the flower has diverse shape, from tubular

Received for publication 4 June 1990. Oregon State Agricultural Experimental Station technical paper no. 9252. The cost of publishing this paper was defrayed in part by the payment of page charges. Under postal regulations, this paper therefore must be hereby marked advertisement solely to indicate this fact.

'Former Graduate Research Assistant. Present address: Istituto di Orticoltura e Floricoltura, Univ- form to semi-open bells (Williams and Rouse, 1983). Within the section Vireya, the hybrid $R$. laetum $\times$ aurigeranum deserves particular attention because of its long-lasting golden yellow flowers that are not found in most common cultivated hardy rhododendrons.

Many species of Rhododendron are currently propagated by tissue culture (Chee, 1985). However, there are no reports concerning the micropropagation of Vireya species. The development of a micropropagation system would facilitate mass propagation of these species. The objective of this research was, therefore, to develop a protocol for the propagation of the Vireya hybrid $R$. laetum $\times$ aurigeranum.

Establishment of shoot-tip cultures. Stock plants of the Vireya hybrid $R$. laetum $\times a u$ rigeranum were grown in 7.7-liter plastic pots containing a 1 perlite $: 1$ peat $: 1$ sandy soil (by volume) mixture. The greenhouse was at 26 to $32 \mathrm{C}$. Plants were watered as needed to keep the medium moist.

Actively growing apical shoot tips, 7 to 8 $\mathrm{cm}$ in length, were collected from the stock plants. All leaves, except those immature leaves enclosing the apical meristem and the leaf primordia, were removed. Shoot tips were rinsed under running tap water for $20 \mathrm{~min}$. The explants were submersed for $2 \mathrm{~min}$ in $70 \%$ ethanol, followed by soaking for $40 \mathrm{~min}$ with gentle agitation in $1.05 \% \mathrm{NaOCl}$ containing 20 drops/liter of Tween 20 . After being rinsed three times in sterile distilled water, the basal ends were removed and shoot tips ( $\approx 5 \mathrm{~cm}$ long) were placed horizontally on 
A

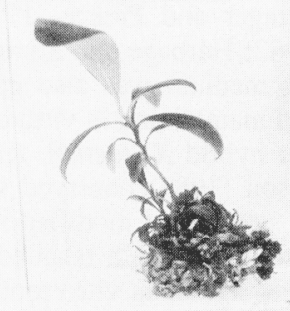

B

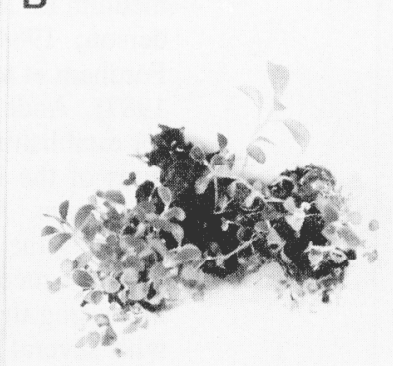

C
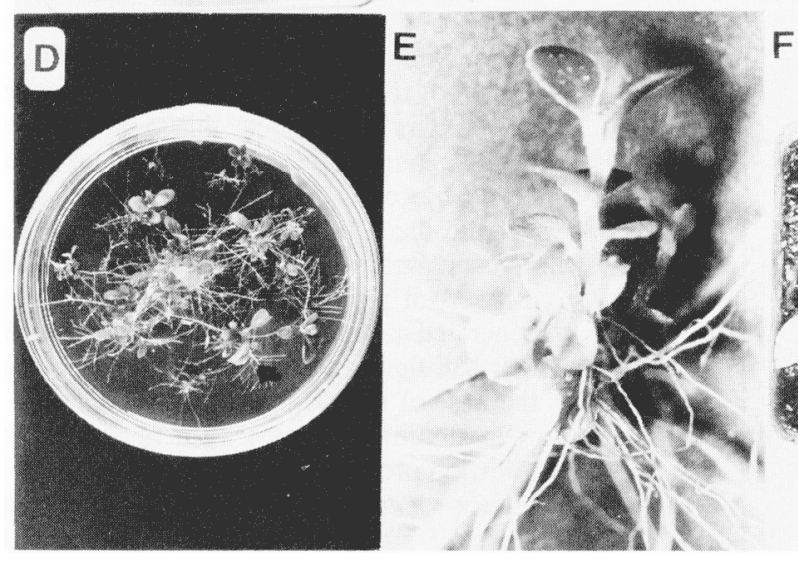

$\mathrm{F}$

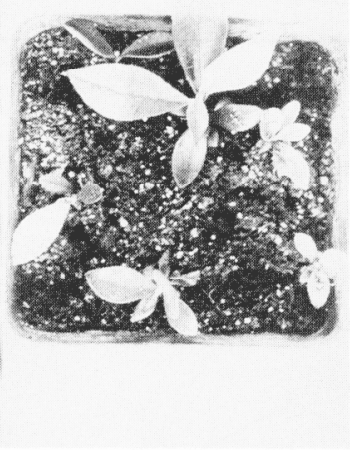

Fig. 1. Adventitious shoot formation from callus of $R$. laetum $\times$ aurigeranum and rootings. (A) Organogenic callus induced at the base of an axillary shoot cultured on Anderson's medium supplemented with IAA and 2iP. (B) Cluster of shoots with small amount of callus proliferated in fresh Anderson's medium with $23 \mu \mathrm{M}$ IAA and $74 \mu \mathrm{M} 2 \mathrm{iP}$. (C) Proliferation of organogenic callus clumps consisting of adventitious shoots and callus tissues. (D) In vitro rooting of adventitious shoots on 1/4-strength Anderson's medium supplemented with $28 \mu \mathrm{M}$ IAA, after 1 month in culture. (E) Plantlets with regenerated root system before transfer to soil. (F) Micropropagated plants 2 months after transplanting to soil.

the surface of various media. Explants were cultured on revised Anderson's medium (Anderson, 1984) containing $88 \mathrm{~mm} \mathrm{su}-$ crose, $560 \mu \mathrm{M}$ inositol, $200 \mu \mathrm{M}$ adenine sulphate, and $8 \mathrm{~g}$ Difco Bacto agar/liter. A 5 $\times 4$ factorial experiment, with all possible combinations of five concentrations of IAA (11 to $34 \mu \mathrm{M}$ ) and four concentrations of 2iP (49 to $172 \mu \mathrm{M}$ ), was used to determine the optimum growth regulator combination for the elongation of axillary shoots. Growth regulators were added to the media before autoclaving. After adjusting the $\mathrm{pH}$ to 4.5 and adding agar, media were autoclave at $121 \mathrm{C}$ for $20 \mathrm{~min}$. Fifty milliliters of medium were dispensed into each sterilized GA7 vessel (Magenta Corp., Chicago).

Explants, one per vessel, were transferred into each of the various media tested. Vessels were sealed with parafilm and incubated at $25 \pm 1 \mathrm{C}$ with a 16 -h photoperiod and 50 $\mu \mathrm{mol} \cdot \mathrm{s}^{-1} \cdot \mathrm{m}^{-2}$ provided by cool-white fluorescent lamps. A completely randomized block design was applied. Five vessels were used for each treatment combination. Treatments were replicated three times over time. Cultures were evaluated for the number of axillary shoots (> $2 \mathrm{~mm}$ in length) after 3 months of culture. The data were subjected to analysis of variance (ANOVA).

Axillary buds started to grow after 1 month of culture. Although the most axillary shoots were induced on medium supplemented with $23 \mu \mathrm{M}$ IAA and $74 \mu \mathrm{M} 2 \mathrm{iP}$ (5.3 shoots per shoot-tip explant), there was not a significant interaction between IAA and 2iP. Furthermore, IAA was not required to induce axillary budbreak, as there was no difference between the media containing 0 to $23 \mu \mathrm{M}$ IAA. Axillary bud proliferation was significantly induced by $74 \mu \mathrm{M} 2 \mathrm{iP}$, whereas lower $2 \mathrm{iP}$ concentrations only stimulated main shoot growth (data not shown). Similar results were observed by Anderson (1984) in the cultivar Scintillation, by Fordham et al. (1982) in 'Exbury' azaleas (Rhododendron spp.), and by Douglas (1984) in several cultivars of Rhododendron grown in Europe. Conversely, lower levels of $2 \mathrm{iP}$ were reported to be effective for some rhododendrons (Blazich et al., 1986; McCown and Lloyd, 1983). The function of $2 \mathrm{iP}$ and other cytokinins is thought to reduce apical shoot dominance and, consequently, induce axillary shoot proliferation (Economou and Read, 1984).

Anderson (1984) and McCown and Lloyd (1983) reported that IAA and 2iP concentrations above certain limits are not effective and/or can be detrimental in inducing Rhododendron multiple shoot formation. This is consistent with our results using $R$. laetum $\times$ aurigeranum. IAA and $2 \mathrm{iP}$ concentrations
$>23$ and $74 \mu \mathrm{M}$, respectively, did not increase the number of axillary shoots (data not shown). Axillary buds of $R$. laetum $\times$ aurigeranum are clustered at the apex of the shoot-tip explant. These buds remain inhibited unless an exogenous stimulus is provialed.

Shoots developed from callus proliferated from axillary shoot-tip explants. Axillary shoots were excised and placed on medium supplied with $23 \mu \mathrm{M}$ IAA and $74 \mu \mathrm{M} 2 \mathrm{iP}$. Brown, friable callus formed at the basal end of the axillary shoots. After $\approx 6$ to 7 months without subculturing, many adventitious shoots were produced from the calli (up to 70 per explant) (Fig. 1A). Clusters of adventitious shoots with small amounts of callus (Fig. 1B) were divided and subculture every 2 months onto fresh medium supplied with $23 \mu \mathrm{M}$ IAA and $74 \mu \mathrm{M} 2 \mathrm{iP}$. This procedure resulted in the greatest average shoot proliferation per callus $(\approx 25$ shoots per chrster) (Fig. 1C). Similar observations were made by McCown and Lloyd (1983) on $R$. canadense, $R . \times$ 'Boule de Neige', and $R . \times$ 'PJM'. We estimated that once organogenic callus is induced, a 1600-fold increase in shoot count in 6 months can be obtained. This protocol represents the most successful method of micropropagating the hybrid $R$. laetum $\times a u$ rigeranum. However, uniformity and genetic stability of the plant material must be carefully evaluated before such a propagation method can be adopted.

Shoot proliferation from adventitious shoots. Individual adventitious shoots ranging from 2 to $10 \mathrm{~mm}$ were excised from callus clusters and placed into $10 \times 60-\mathrm{mm}$ petri dishes containing $10 \mathrm{ml}$ of Anderson's medium supplemented with various combinations of IAA (11 to $34 \mu \mathrm{M}$ ) and 2iP (49 to $172 \mu \mathrm{M}$ ) concentrations. A completely randomized design was used, with five replicates per treatment. A replication was defined as a petri dish containing four single shoots. Explants were subculture every 2 months, and the number of newly formed shoots per individual shoot explant was recorded after 6 months of culture. ANOVA was performed to evaluate the effects of each main effect, as well as interactions.

A small amount of callus and green shoot primordia developed from the base of individual adventitious shoots after 2 months in culture. The primordia differentiated into small leaves. New shoots were distinguished as they emerged from the mass of leaves after 6 months of culture. There was no significant difference among $2 \mathrm{iP}$ treatments, nor was there any interaction between the growth regulators. However, $34 \mu \mathrm{M}$ IAA with all concentrations of $2 \mathrm{iP}$ was most effective for inducing new shoot formation from the basal end of single shoots (7.4 shoots per single shoot), compared to lower levels of IAA (data not shown). The average number of shoots per single shoot obtained in this experiment (about seven shoots per cultured shoot) was considerably smaller than that obtained when clumps of shoots with small amounts of callus were routinely subculture $(\approx 40$ shoots per cultured shoot clump). 


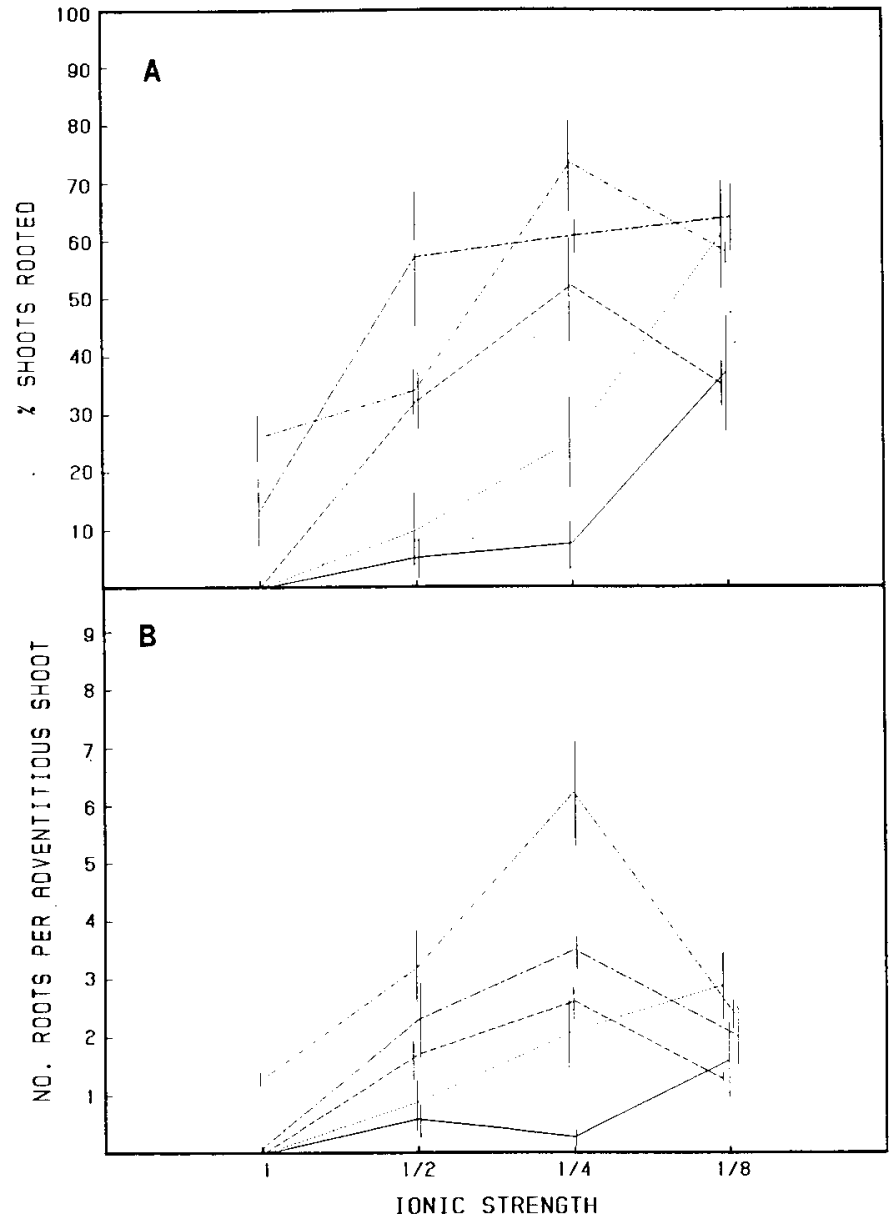

Fig. 2. Effect of ionic strength and IAA concentration on percentage of rooted adventitious shoots (A) and on the number of roots per adventitious shoot (B) of $R$. laetum $\times$ aurigeranum after 1 month of culture. Vertical bars represent \pm SE. (-) $0 \mu \mathrm{M}$ IAA; (. . .) $0.6 \mu \mathrm{M} \mathrm{IAA;} \mathrm{(-} \mathrm{-} \mathrm{-} \mathrm{-)} 6 \mu \mathrm{M}$

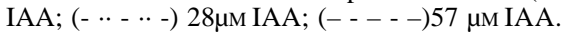

Rooting and establishment in the soil. To determine the optimum conditions for in vitro rooting of microshoots, four concentrations of the salts in Anderson's medium (1, $1 / 2,1 / 4$, and $1 / 8$ strength) with five IAA concentrations $(0,0.6,6,28$, and $57 \mu \mathrm{M})$ in a factorial experiment were used. A completely randomized design was used with five replicates. A replication consisted of a petri dish containing nine adventitious shoots. Data were recorded as percentage of shoots rooted after 4 weeks and number of roots per shoot. Percentage data were subjected to arcsin transformation before ANOVA analysis.

Rooted plantlets (Fig. 1D and E) were removed from culture medium, and agar was washed from the roots. Plantlets were then transplanted into compost (Jiffy Mix Plus; Jiffy Products of America, Bataria, Ill.) in seed trays and covered with clear plastic bags to maintain a high relative humidity. The compost was kept moist by frequent watering, and seed trays were kept in a greenhouse under the same growth conditions as the stock plants. Ventilation of the plantlets was increased with time by increasing the size of the holes made in the bags, and after 1 week, the plastic bags were removed. The percentage of plants that were successfully rooted was determined 3 weeks after transplanting.
In vitro rooting of excised shoots was accomplished in $\approx 1$ month. Ionic concentration of Anderson's medium in combination with concentrations of IAA influenced the rooting of shoots (Fig. 2A). Given the significant ionic strength $\times$ IAA concentration interaction, valid comparisons among IAA concentrations can be made only within ionic strengths. Absent or low levels of IAA $(<28$ $\mu \mathrm{M})$ in combination with full-strength Anderson's medium resulted in no rooting. Using $1 / 4$ ionic strength, the percentage of rooted plants ranged from $7.8 \%$ with $0 \mu \mathrm{M}$ IAA to $73 \%$ with $28 \mu \mathrm{M}$ IAA. About $60 \%$ rooting was obtained using $1 / 8$ ionic strength and $0.6,28$, or $57 \mu \mathrm{M}$ IAA. The percentage of rooted plants was significantly increased by increasing IAA concentrations and lowering the ionic concentrations. The highest value of in vitro-rooted shoots (73\%) was obtained on medium with $1 / 4$ strength supplemented with $28 \mu \mathrm{M}$ of IAA.

The number of roots per shoot was also affected by the treatments tested, and again a significant interaction was found between IAA concentrations and ionic strength (Fig. 2B). The highest value, six roots per plant, was recorded using 1/4 ionic strength and 28 $\mu \mathrm{M}$ IAA.

The low-salt medium developed by An- derson has been recognized as a suitable medium for several Rhododendron spp. (Anderson, 1984; Ettinger and Preece, 1985; Fordham et al., 1982; Harbage and Stimart, 1987). Anderson's medium was also good for establishing and maintaining in vitro cultures of the Vireya hybrid R. laetum $\times a u$ rigeranum. Anderson (1984) observed that lowering the ionic strength of modified Anderson's medium to $1 / 4$ strength resulted in increasing the percentage of in vitro rooting with several cultivars of Rhododendron. In our experiment, the low ionic salt concentration of the medium and the IAA concentrations interacted significantly to induce in vitro root formation in $R$. laetum $\times$ aurigeranum. It is also evident that a critical level of IAA must be reached before root induction can occur.

All rooted plantlets transferred to soil survived regardless of the medium used to induce rooting (Fig. 1F). Plants on soil generated new roots from the root system that had developed in vitro and, later, from the base of the plantlets.

In summary, a successful in vitro multiplication protocol has been developed for $R$. laetum $\times$ aurigeranum. Among the three types of shoot multiplication, adventitious shoot multiplication from organogenic callus, induced at the cut surfaces of the axillary shoot-tip explants, gave the best results.

\section{Literature Cited}

Anderson, W.C. 1984. A revised tissue culture medium for shoot multiplication of rhododendron. J. Amer. Soc. Hort. Sci. 109:343-347.

Blazich, F. A., C.G. Giles, and C.M. Haemmerle. 1986. Micropropagation of Rhododendron chapmanii. J. Env. Hort. 4:26-29.

Chee, R. 1985. The history of Rhododendron micropropagation provides some tips for success. Amer. Nurseryman 5:42-47.

Douglas, G.C. 1984. Propagation of eight cultivars of Rhododendron in vitro using agar-solidified and liquid media and direct rooting of shoots in vivo. Scientia Hort. 24:337-347.

Economou, A.S. and P.E. Read. 1984. In vitro shoot proliferation of Minnesota deciduous azaleas. HortScience 19:60-61.

Ettinger, T.L. and J.E. Preece. 1985. Aseptic micropropagation of Rhododendron P.J.M. hybrids. J. Hort. Sci. 60:269-274.

Fordham, I., D.P. Stimart, and R.H. Zimmerman. 1982. Axillary and adventitious shoot proliferation on Exbury azaleas in vitro. HortScience 17:738739.

Harbage, J.F. and D.P. Stimart. 1987. Adventitious shoot regeneration from subculture callus of Rhododendron Exbury hybrids. HortScience 22:1324-1325.

Leslie, A. (ed.). 1980. The rhododendron handbook-Rhododendron species in cultivation. The Royal Horticultural Society, London.

McCown, B.H. and G.B. Lloyd. 1983. A survey of the response of Rhododendron to in vitro culture. Plant Cell Tissue Organ Culture 2:77-85.

Sleumer, H.O. 1966. An account of Rhododendron in Malesia. Flora Malesiana Ser. 1:474-668.

Withers, R.M. 1984. The natural environment of $\mathrm{Vi}$ reya rhododendrons. Proc. Royal Hort. Soc., London. p. 20-24.

Williams, E.G. and J.L. Rouse. 1988. Disparate style lengths contribute to isolation of species in Rhododendron. Austral. J. Bet. 36:183-191. 